\title{
Military expenditure and economic growth in the European Union: Evidence from SIPRI's extended dataset
}

\section{Julien Malizard}

Julien Malizard is Senior Researcher at the Chair of Defense Economics in the Endowment Fund of the Institute for Higher National Defense Studies (Institut des Hautes Etudes de Défense Nationale) in Paris, France. He is also a Research Fellow at the Research Unit in Theoretical and Applied Economics (GREThA), University of Bordeaux. He may be reached at julien.malizard@fdd-ihedn.fr or julien.malizard@gmail.com.

\section{Abstract}

The aim of this article is to shed light on the fiscal consequences of economic growth in the EU15 countries by disentangling military and civilian government expenditure. Given the newly available extended dataset on military expenditure provided by the Stockholm International Peace Research Institute (SIPRI), a comparison can be made to older SIPRI data. Using growth theory and panel data analysis, the results show that public spending is growth detrimental and military expenditure is less harmful than nonmilitary, civilian spending. The new data offer a richer pattern of results.

$\mathrm{T}$ he economic crisis that began in the late 2000s has spurred economists to (re)evaluate the macroeconomic consequences of public sector spending. No consensus has emerged which makes it difficult to address policy options. For European countries, especially, estimating the influence of public expenditure is a major issue as many of them have reached public debt limits stipulated by Maastricht criterion. The subsequent fiscal consolidation then raised questions regarding the consequence of debt limits on current economic performance. The aim of this article is to provide empirical evidence of the long-run effect of public expenditure in the EU15 countries by comparing military and nonmilitary, civlian public expenditure. ${ }^{1}$

Military expenditure lies at the intersection of security needs and budgetary constraints: A rise in perceived threats should lead to a rise in military expenditure whereas bad economic conditions could have an adverse effect on military outlays. Recent trends in the EU15 show that following the fiscal consolidation policy, military expenditure fell by an average of 12.5 percent between 2010 and 2014, especially so in countries most severely affected by the economic crisis, i.e., Greece, Italy, Portugal, and Spain. (Among the EU15, only Sweden showed a rise in military expenditure for the 2010-2014 period.) At the same time, the EU15 are facing increased threats: For instance, the attitude of Russia appears somewhat aggressive and generates uncertainties regarding Crimea, terrorists' attacks have taken place in Paris and elsewhere in Europe, and a number of European countries are involved in the international coalition against ISIS. The nature of many of these kinds of threats is more diffuse than before so that security issues raise challenges not yet fully taken into account by European defense strategy. ${ }^{2}$

To deal with these events, military budgets are being increased. Thus, France decided to raise its budget by EUR3.5 billion to finance the deployment of land forces within the country. Equipment-poor Germany approved a budget increase of EUR6.2 billion for the five next years. The United Kingdom's 2015 Strategic Defence and Security Review acknowledges that the 2 percent of GDP target is necessary and commits to respect this threshold in the future. As a final example, the newly elected Finnish government imposed public spending cuts except for the military.

These choices have economic consequences. The literature on the military expenditure-economic growth relation is not entirely conclusive, in part because of differences in theoretical approaches, samples, and econometric modeling. Channels by which military expenditure may affect economic growth are numerous so that constructing a model that would encompass all the channels is very difficult to implement and estimate. Some research papers dealing with the EU15 suggest that military expenditure has an adverse influence on economic growth but generalizing across a group of countries that are fairly heterogeneous in their defense and economy policies may give one pause. ${ }^{3}$

In this article, I rely on growth theory as it provides a useful framework to evaluate the role of public spending. The growth effects of fiscal policy have been widely investigated, and the literature concludes that public spending exerts a negative influence on growth. However, empirical difficulties arise due to implied homogeneity which can lead to flaws in estimation. 
This article studies the relation between military expenditure and economic growth for the EU15 countries. Using the newly revised and extended SIPRI military expenditure dataset, the article finds that over the 1960-2011 time period, both military and nonmilitary expenditure exert a negative effect on per capita economic growth, and nonmilitary spending more so than military spending.

To avoid this problem, some authors control for potential heterogeneity. I follow this part of the literature as it allows one to capture steady-state dynamics with a long time series panel. This point is original to the military expenditure-economic growth literature. ${ }^{4}$

One key issue to get comprehensive and consistent data on military expenditure. For comparative studies this requires that the definition of military expenditure is strictly identical across countries. SIPRI's data have become a standard source in the literature because its method is fully available and it uses consistent definition over time and among countries. One limitation, however, of SIPRI's original data was its relatively short time coverage, 1988-2015. This has now been rectified with data for a number of countries going back to the early 1950 s, providing an opportunity to evaluate the dynamics of the military expenditure-economic growth relation in a panel data context for the EU15 countries. ${ }^{5}$

The remainder of this article is organized as follow. The next section presents the theoretical model and the data. The follow-on section discusses the issue of country heterogeneity and how to address it in terms of econometric method used. Results are provided in the section thereafter, and the article concludes with thoughts on future research.

\section{Model and data}

I employ a standard endogenous growth model with human capital and public expenditure. With this specification, the growth rate of GDP per capita, i.e., $\ln \left(y_{t}\right)-\ln \left(y_{t-1}\right)$, is determined by physical capital $\left(s_{t}\right)$, human capital $\left(h_{t}\right)$, the population growth rate $\left(n_{t}\right)$, military expenditure $\left(m_{t}\right)$ and nonmilitary expenditure $\left(\text { civil }_{t}\right)^{6}{ }^{6}$

To deal with the absence of transitional dynamics in this kind of model, recent literature assumes that the model can be reparametrized as an autoregressive distributed lag (ARDL). This takes the following form:

(1) $\ln \left(y_{t}\right)-\ln \left(y_{t-1}\right)=-\theta \ln \left(y_{t-1}\right)+\alpha_{1} \ln \left(s_{t}\right)+\alpha_{2} \ln \left(h_{t}\right)+\alpha_{3} \ln \left(n_{t}\right)+$ $\alpha_{4} \ln \left(m_{t}\right)+\alpha_{5} \ln \left(\right.$ civil $\left._{t}\right)+\beta_{1} \Delta \ln \left(s_{t}\right)+\beta_{2} \Delta \ln \left(h_{t}\right)+\beta_{3} \Delta \ln \left(n_{t}\right)+$ $\beta_{4} \Delta \ln \left(m_{t}\right)+\beta_{5} \Delta \ln \left(\right.$ civil $\left._{t}\right)+\epsilon_{t}$,

where $\Delta$ denotes the first difference operator and $\epsilon_{t}$ the error

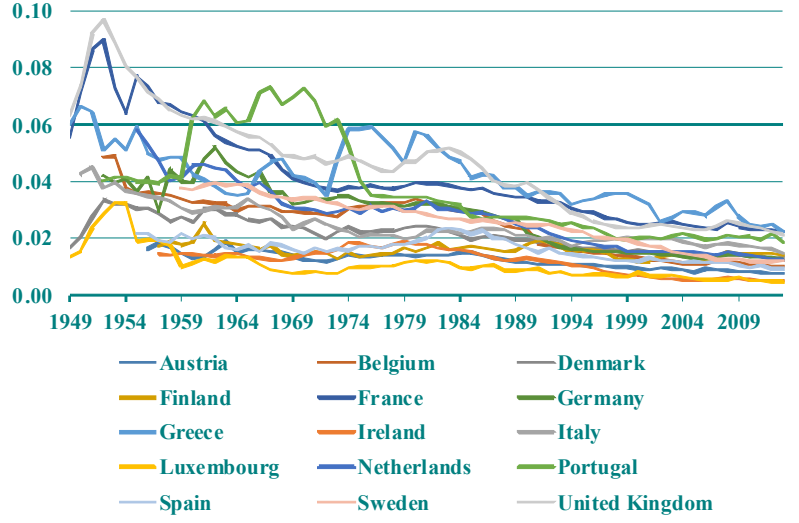

Figure 1: EU15 defense burdens (military expenditure as percent of GDP), 1949-2014. Source: SIPRI.

term. As written, the equation has only one lag term but it can be augmented with ease to include more. To estimate equation (1), I assume that $s_{t}$ is equal to the investment ratio.

Military expenditure, as indicated, is taken from SIPRI's database, covering the 1988-2015 period (the "old" data) and a longer ("new" data) period going back to the early 1950 s. Since data availability differs for the EU15, the period used in this article is 1960-2011, ensuring a balanced panel. The data for all other variables used are taken from the Penn World Table v8.1 (PWT) which covers 1950-2011. The dependent variable is the real growth rate of GDP per capita, computed as the first difference of real GDP per capita. Investment is captured as the ratio of investment to GDP, a proxy for physical capital $(s)$. Population growth follows standard growth econometrics by augmenting it with exogenous elements, $g+d$, equal to five percent. Human capital is indexed in the Penn World Table and computed as the average years of schooling along with an assumed rate of return on primary, secondary, and tertiary education. Nonmilitary public spending as a share of GDP is calculated as the difference between the public spending share and the military spending share in GDP. Note that transfer payments are not included.) Finally, military expenditure, in the form of its share in GDP (the defense burden), is computed by and taken from SIPRI. ${ }^{7}$

Plotting the defense burden for each of the EU15 countries, Figure 1 shows a general downward trend and convergence of the majority of the EU15 defense burdens below two percent of GDP. In contrast to other publicly available data, SIPRI's extended dataset includes the cold war period, and the figure illustrates the evolution of the defense burden over the entire time span. The defense burden range (maximum minus minimum defense burden) has declined over time, even as distinct defense burden patterns can be identified among countries, as discussed in the next section. ${ }^{8}$ 


\section{Heterogeneity}

The EU15 countries features many differences in terms of their defense and economic policies. It therefore appears crucial to identify the main sources of heterogeneity so as to control for them properly in any statistical work. This section discusses reasons for the heterogeneity among the EU15 countries. Table 1 shows the defense burden for different subsamples (the average defense burden within each subsample is unweighted). ${ }^{9}$

The primary aim of military expenditure is to provide security and to deter enemy aggression. The cold war era was a period of high risk since the countries of the Warsaw pact, notably the then-Soviet Union, was viewed as a threat to Western Europe. To deter attack, EU15 countries devoted a larger share of GDP to the military during the cold war years (2.96 percent) than thereafter ( 1.76 percent). ${ }^{10}$

Defense policy drives in part on the existence of a defense industry. To maintain a measure of control over procurement, a country may develop in its own defense industry. Some countries produce the (nearly) complete scope of defense goods for air, naval, and land forces (France and the U.K.) and others manufacture major platforms such as aircraft, frigates, or tanks (Germany, Italy, Spain, and Sweden). Technologically advanced, these platforms require massive investment in R\&D. Still other countries specialize in certain defense items such as small arms (Belgium). Major producers are known as the Letter of Intention (LoI) countries, a group composed of France, Germany, Italy, Spain, Sweden, and the UK. Their defense industries are viewed as strategic industries both for procurement autonomy and for economic reasons. In Table 1, the average defense burden for LoI members is 2.83 percent, as compared to 2.2 percent for non-LoI members. ${ }^{11}$

Among LoI members, France and the U.K. share common defense policy features. Permanent members of the UN Security Council, both take fairly interventionist postures vis-à-vis overseas operations and see nuclear deterrence as a policy pillar. Their strategic ambitions are considered as higher than those of the other EU15 countries. Unsurprisingly, then, in absolute terms France and the U.K. are the EU15 biggest military spenders. ${ }^{12}$

NATO membership also affects defense policy decisions. Among the EU15, only four countries are not members of the alliance (Austria, Finland, Ireland, and Sweden). To allow the defense burden to be shared fairly, NATO members have to fulfill a list of budgetary commitments. Specifically, each members' defense budget should be above 2 percent of GDP and defense equipment spending should equal at least 20 percent of the defense budget. In 2014, the latter criteria was met only by France, Greece, Portugal, and the U.K. The
Table 1: Heterogeneity defense policy, 1960-2011

$\begin{array}{lcc} & \begin{array}{c}\text { Number of } \\ \text { observations }\end{array} & \begin{array}{c}\text { Average } \\ \text { defense } \\ \text { burden }\end{array} \\ \text { Full sample } & 480 & 0.0245 \\ \text { Cold war period } & 330 & 0.0296 \\ \text { Post-cold war period } & 312 & 0.0176 \\ \text { LoI members } & 468 & 0.0283 \\ \text { Non-LoI members } & 104 & 0.0388 \\ \text { Nuclear powers } & 676 & 0.0223 \\ \text { Nonnuclear powers } & 575 & 0.0274 \\ \text { NATO members } & 208 & 0.0167 \\ \text { non-NATO members } & & \\ \begin{array}{l}\text { Note: LoI = Letter of Intent countries. See text for explanation. } \\ \text { Source: Computed from SIPRI data. }\end{array}\end{array}$

equipment criteria was met, in 2013, only by France and the U.K. Nonetheless, NATO members spend a significantly larger share of GDP on defense as compared to non-NATO members (2.74 versus 1.67 percent; see Table 1$).^{13}$

In light of these differences, assuming parameter homogeneity in the estimation of equation (1) would seem peculiar. In growth econometrics, homogeneity means that each country has the same production function. This assumption has been criticized as too restrictive. In recent years, the assumption of a common production function has been relaxed and authors of comparative studies conclude that homogeneity leads to estimation bias, so that "empirical exercises which fail to incorporate parameter heterogeneity are likely to produce misleading results." ${ }^{14}$

From an econometric perspective, standard Dynamic Fixed Effect (DFE) estimation implies homogeneity in slopes which is not suitable to estimate the model in equation (1). Two alternative estimators are considered. A Mean Group (MG) estimator estimates the model for each country and calculates averages so that no restrictions are imposed. An intermediate path is the Pooled Mean Group (PMG) estimator which allows the short-run coefficients and the error correction term to be heterogeneous but imposes homogeneity on the long-run coefficients. This article uses the PMG estimator method. Empirically, the hypothesis of long-run homogeneity for developed countries is confirmed in recent articles, and modern 
growth econometrics uses this estimator as it better fits the data to the underlying model. Moreover, the PMG estimator fits an error correction model which appears to be suitable in macro panel data. Finally, endogeneity is a major concern in the growth literature but the ARDL approach is appropriate to overcome this issue. ${ }^{15}$

In a panel setting, and given the PMG approach, equation (1) becomes:

$$
\text { (2) } \begin{aligned}
& \ln \left(y_{i t}\right)=-\theta_{i} \ln \left(y_{i, t-1}\right)-\gamma_{1} \ln \left(s_{i t}\right)-\gamma_{2} \ln \left(h_{i t}\right)-\gamma_{3} \ln \left(n_{i t}\right) \\
& -\gamma_{4} \ln \left(m_{i t}\right)-\gamma_{5} \ln \left(c i v i l_{i t}\right)+\beta_{1, i} \ln \left(s_{i t}\right)+\beta_{2, i} \ln \left(h_{i t}\right)+ \\
& \beta_{3, i} \ln \left(n_{i t}\right)+\beta_{4, i} \ln \left(m_{i t}\right)+\beta_{5, i} \ln \left(c i v i l_{i t}\right)+\epsilon_{i t},
\end{aligned}
$$

where the subscript $i$ denotes countries, $\gamma_{i}=\theta_{i} / \alpha_{i}$. The other notations are unchanged. Estimating the long-run relationship consists of evaluating all the $\gamma_{i}$ coefficients. In the following, I rely only on these coefficients. Unit root (Im, Pesaran and Shin) and cointegration (Pedroni) tests have been conducted (see Appendix). They conclude that, except for human capital, each variable is nonstationary and a long-run cointegrating vector exists among them.

\section{Results}

The results are presented in Table 2. Note that the estimations use one lag to compute the error correction model thanks to the PMG estimator. Alternative estimators (Mean Group or Dynamic Fixed Effect) are not presented here because Hausman tests show the superiority of the PMG estimator. The dependent variable is the real growth rate of GDP per capita.

The exercise was run twice, once for the "old" SIPRI data (1988-2011) and once for the extended SIPRI data 1960-2011. An unbalanced panel was estimated as well with the longest time span for each country. Compared to the 1960-2011 results shown here, there are no significant changes. ${ }^{16}$

Almost all of the control variables come in with the expected sign. For both periods, investment is statistically significant and positive, with only a small coefficient change. Population growth exerts a negative influence, less adverse for the shorter than for the longer time period. The ECT is statistically significant and negative, as suggested by econometric theory.

Contrary to theoretical expectation, human capital appears statistically insignificant for both periods. One explanation may lie in the construction of the human capital variable (which is not consistent with many recent works) which includes a rate of return of schooling. But a model estimated without human capital is consistent with the results in Table $2 .{ }^{17}$

Turning to the fiscal policy variables, major changes are

\begin{tabular}{|c|c|c|}
\hline & $1960-2011$ & $1988-2011$ \\
\hline Investment ratio (s) & $\begin{array}{c}0.1698^{* * * *} \\
(0.0214)\end{array}$ & $\begin{array}{c}0.1728 * * * \\
(0.0290)\end{array}$ \\
\hline Population growth (n) & $\begin{array}{c}-2.4133 * * * \\
(0.7932)\end{array}$ & $\begin{array}{c}-1.6955^{* * *} \\
(0.5964)\end{array}$ \\
\hline Human capital (h) & $\begin{array}{c}0.2916 \\
(0.4821)\end{array}$ & $\begin{array}{c}0.7825 \\
(0.5588)\end{array}$ \\
\hline Military expenditure (m) & $\begin{array}{c}-1.1088 * * * \\
(0.2431)\end{array}$ & $\begin{array}{l}-0.2463 \\
(0.5964)\end{array}$ \\
\hline Nonmilitary exp. (civil) & $\begin{array}{c}-2.8680^{* * * *} \\
(0.6912)\end{array}$ & $\begin{array}{c}-0.8434 * * \\
(0.3593)\end{array}$ \\
\hline$E C T$ & $\begin{array}{c}-0.0213 * * * \\
(0.0043)\end{array}$ & $\begin{array}{c}-0.0693 * * * \\
(0.0124)\end{array}$ \\
\hline Number of observations & 780 & 360 \\
\hline $\begin{array}{l}\text { Tote: Standard errors in bro } \\
\text { tatistical significance at th } \\
\text { espectively. ECT stands fo }\end{array}$ & $*, * *$ and $*$ & $\begin{array}{l}\text { denote } \\
\text { t levels, } \\
\text { m. }\end{array}$ \\
\hline
\end{tabular}
observed between the two time periods. First of all, public
Table 2: Long-run estimates

spending as a whole (military and nonmilitary) generates a negative effect on per capita growth, a finding which in is line with recent growth econometrics literature. This means that the negative influence of taxation dominates any positive influence of public spending (externality) on the private sector. However, splitting public expenditure between military and nonmilitary results in a different outcome. For the 1960-2011 period, both military and nonmilitary expenditure exert a detrimental effect on growth (and the coefficient for nonmilitary expenditure more so than that for military expenditure). But the 1988-2011 period, though, no statistically significant effect is observed for military expenditure whereas its nonmilitary counterpart still is growth damaging. The coefficients for the shorter time period are quite a bit smaller (less harmful) than for the longer period. ${ }^{18}$

Why would nonmilitary (civilian) public expenditure appear to be more harmful for per capita growth than military expenditure for the 1960-2011 period? One explanation may lie in the level of military expenditure which is very much smaller lower than the level of nonmilitary expenditure and, smaller yet, for mostly post-cold war world of 1988-2011. A second explanation may lie in the composition of military expenditure: For the major countries, the military concentrates a high proportion of public investment, due to procurement, whereas nonmilitary expenditure consists mainly of civil service wages. The negative influence of day-to-day civilian public sector wage expenditure is cancelled out by the positive 
effect of military equipment expenditures.

In sum, compared to prior research, use of SIPRI's extended military expenditure data and estimating a dynamic model (with ECM) offer a new perspective on the military expenditure-economic growth relationship for the EU15 area.

\section{Conclusion}

The research reported in this article evaluates the long-term economic growth consequences of public expenditure by disentangling military from nonmilitary expenditure for the EU15 countries. It relies on an augmented Solow growth model and PMG estimators which allows one to take heterogeneity among countries into account. Moreover, the extended dataset permits one to investigate the dynamics of the relation with an error correction approach. The results indicate that the effects of military and nonmilitary expenditure are not equal. For the shorter time period-1988-2011-military expenditure does not exhibit a statistically significant adverse impact on growth whereas nonmilitary spending does. For the longer period-1960-2011-both military and nonmilitary expenditure impede economic growth but nonmilitary spending more so than military spending.

One issue is to learn whether changes in the composition of public expenditure are growth promoting. The results provided in this article do not offer a clear answer to this question: For the shorter time period, the estimated coefficient of military spending is negative but not statistically significant but for the longer period, it is both significant and negative. According to the results coming off the extended dataset, one cannot expect a positive influence on long-term growth from a reallocation of public spending from the military to the nonmilitary sector.

The research reported here can be enriched in at least three ways. First, significant economic consequences can flow from the way public expenditure is financed (with deficits or via direct or indirect taxes). If included in the analysis, different findings may result. Second, military expenditure is a response to perceived or actual threats, so that security needs may need to be included in the analysis, e.g., with an interaction term between military expenditure and threats. Third, composition issues (e.g., splitting military expenditure between equipment and day-to-day spending) are probably quite relevant for a more complete understanding of the relationship between public sector spending and economic growth. ${ }^{19}$

\section{Notes}

1. No consensus: See, e.g., Hebous (2011). Debt limit: Reinhart and Rogoff (2010) reinvestigate the debt-growth relationship and argue that if public debt is above 90 percent of GDP, it impedes economic growth. Although criticized, their paper has been widely discussed given its policy implication.
2. On Russia: In a recent interview, NATO Secretary General Jens Stoltenberg acknowledges that "we have to deal with a more aggressive behavior from Russia at the east." Le Monde (6 June 2016). Defense strategy: For instance, Schmidt (2013) argues that Europe's Common Security and Defence Policy (CSDP) is ineffective. Sherpherd (2016) argues that due to their increasing interconnections, the distinction between internal and external security threats is no longer relevant.

3. Not entirely conclusive: For a recent survey, see Dunne and Tian (2013). Numerous channels: See Dunne, Smith, and Willenbockel (2005) for a general discussion. Negative effect in EU15 countries: E.g., Kollias, Mylonidis, and Paleologou (2007), Mylonidis (2008), and Dunne and Nikolaidou (2012) for a growth model in a panel setting. Chang, Lee, and Chu (2015) use a Granger-causality test rather than a growth model. Heterogeneous EU15: Dunne and Nikolaidou (2012).

4. Framework: Barro (1991) published the pioneering work and shows that there exists an optimal value of public spending when the positive externality of public services equals the negative impact of taxation. The literature concludes: Bergh and Henrekson (2011). Homogeneity: As noted by Brock and Durlauf (2001, pp. 8-9), "the assumption of parameter homogeneity seems particularly inappropriate when one is studying complex heterogeneous objects such as countries." Some authors: See, e.g, Arnold, et al. (2011a) and Gemmel, Kneller, and Sanz(2016) for an evaluation of fiscal policy.

5. Standard source: See Smith (2009).

6. Standard growth model: See Mankiw, Romer, and Weil (1992) for the pioneering work.

7. Note that human capital data is available from the OECD for shorter time spans and has often been used in research papers in the form of averages years of schooling. Use of the PWT data in this article is original.

8. Convergence: For discussion, see Arvanitidis, Kollias, and Anastopoulos (2014). Two percent: NATO set a threshold, stating the its members each should spend at least two percent of GDP on military expenditure. Of the EU15 countries, 11 are NATO members.

9. Obviously, major differences arise between EU15 countries with respect to their economic policies (e.g., euro membership, fiscal policies, social preferences for public expenditure). In this article, I focus on defense policy differences.

10. The $t$-statistic for the mean difference is 14.29.

11. The $t$-statistics is a statistically significant 10.05 . One referee rightly argues that among LoI members, nuclear powers have a prominent place. The average defense burden for the four non-nuclear LoI members is 2.32 percent which is close to the non-LoI average but still statistically significantly different from them (the relevant $t$-statistic equals 3.95).

12. Policy pillar: The French White Paper on Defense and Security insists on the need of nuclear deterrence. In the U.K., the recent Strategic Defence and Security Review points out that the Trident nuclear force has to be replaced to fulfill its 
commitments to Britain's defense strategy. For both countries, the only option considered is Continuous-At-Sea Deterrence, which requires at least four submarines. Strategic ambitions: Smith (2009).

13. Regarding the 2 percent criterion, note that SIPRI's definition varies from NATO's. Using NATO data, only Greece and the U.K. respect the criterion.

14. Assumption has been criticized: For a survey, see Eberhardt and Teal (2011). Quote: Durlauf, Kourtellos, and Minkin (2001, p. 935).

15. PMG estimator: This method was developed by Pesaran, Shin, and Smith (1999). Recent articles: See, e.g., Arnold et al. (2011b) among others. Better fits the data: Gemmell, Kneller, and Sanz (2016). Macro panel data: Eberhardt and Presbitero (2015).

16. Unbalanced panel: Not shown but available upon request.

17. Rate of return: See Temple (2001) for discussion.

18. Results for the combined public expenditure variable are available upon request.

19. Second: See Aizenman and Glick (2006). Third: Among recent contributions, see, e.g., d'Agostino, Dunne, and Pieroni (2011) and Malizard (2015).

\section{References}

Aizenman, J. and R. Glick. 2006. "Military Expenditure, Threats and Economic Growth.” Journal of International Trade and Economic Development. Vol. 15, No. 2, pp. 129-155. http://dx.doi.org/10.1080/09638190600689095

Arnold, J., B. Brys, C. Heady, Å. Johansson, C. Schwellnus, and L. Vartia. 2011a. "Tax Policy for Economic Recovery and Growth.” The Economic Journal. Vol. 121, pp. 59-80. http://dx.doi.org/10.1111/j.1468-0297.2010.02415.x

Arnold J., A. Bassanini, and S. Scarpetta. 2011b. "Solow or Lucas? Testing Speed of Convergence on a Panel of OECD Countries." Research in Economics. Vol. 65, No. 2, pp. $110-123$. http://dx.doi.org/10.1016/j.rie.2010.11.005

Arvanitidis, P., C. Kollias, and C. Anastopoulos. 2014. "Is there an International Convergence in Defence Burdens? Some Initial Findings." Peace Economics, Peace Science and Public Policy. Vol. 20, No. 4, pp. 611-620. http://dx.doi.org/10.1515/peps-2014-0030

Barro, R.J. 1991. "Government Spending in a Simple Model of Endogenous Growth." Journal of Political Economy. Vol. 98, No. 5, pp. 103-125.

http://dx.doi.org/10.1086/261726

Bergh, A. and M. Henrekson. 2011. "Government Size and Growth: A Survey and Interpretation of the Evidence." Journal of Economic Surveys. Vol. 25, No. 5, pp. 872-897. http://dx.doi.org/10.1111/j.1467-6419.2011.00697.x

Brock, W. and S. Durlauf 2001. "Growth Economics and Reality." World Bank Economic Review. Vol. 15, No. 2, pp. 229-272. http://dx.doi.org/10.1093/wber/15.2.229

Chang, T., C.-C. Lee, and H.-P. Chu. 2015. "Revisiting the Defense-Growth Nexus in European Countries." Defence and Peace Economics. Vol. 26, No. 3, pp. 341-356. http://dx.doi.org/10.1080/10242694.2013.832556

d'Agostino, G., J.P. Dunne, and L. Pieroni. 2011. "Optimal Military Spending in the U.S.: A Time Series Analysis." Economic Modelling. Vol. 28, No. 3, pp. 1068-1077. http://dx.doi.org/10.1016/j.econmod.2010.11.021

Dunne, J.P., R.P. Smith, and D. Willenbockel. 2005. "Models of Military Expenditure and Growth: a Critical Review." Defence and Peace Economics. Vol. 16, No. 6, pp. 449-460.

http://dx.doi.org/10.1080/10242690500167791

Dunne, J.P. and E. Nikolaidou. 2012. "Defence Spending and Economic Growth in the EU15." Defence and Peace Economics. Vol. 23, No. 6, pp. 537-548. http://dx.doi.org/10.1080/10242694.2012.663575

Dunne, J.P. and N. Tian. 2013. "Military Expenditure and Economic Growth: A Survey." Economics of Peace and Security Journal. Vol. 8, No. 1, pp. 5-11. http://dx.doi.org/10.15355/epsj.8.1.5

Durlauf, S., A. Kourtellos, and A. Minkin. 2001. "The Local Solow Growth Model." European Economic Review. Vol. 45, Nos. 4-6, pp. 928-940. http://dx.doi.org/10.1016/S0014-2921(01)00120-9

Eberhardt, M. and F. Teal. 2011. "Econometrics for Grumblers: A New Look at the Literature on Cross-Country Growth Empirics." Journal of Economic Surveys. Vol. 25, No. 1, pp. 109-155. http://dx.doi.org/10.1111/j.1467-6419.2010.00624.x

Eberhardt, M. and A. Presbitero. 2015. "Public Debt and Growth: Heterogeneity and Non-Linearity." Journal of International Economics. Vol. 97, No. 1, pp. 45-58. http://dx.doi.org/10.1016/j.jinteco.2015.04.005

Gemmell, N., R. Kneller, and I. Sanz. 2016. "Does the Composition of Government Expenditure Matter for Long-Run GDP Levels?" Oxford Bulletin of Economics and Statistics. Vol. 78, No. 4, and pp. 522-547.

Hebous, S. 2011. "The Effects of Discretionary Fiscal Policy on Macroeconomic Aggregates: A Reappraisal." Journal of Economics Surveys. Vol. 25, No. 4, pp. 687-707. http://dx.doi.org/10.1111/j.1467-6419.2010.00659.x

Kollias, C., N. Mylonidis, and S.-M. Paleologou. 2007. "A Panel Data Analysis of the Nexus between Defence Spending and Growth in the European Union." Defence and Peace Economics. Vol. 18, No. 1, pp. 75-85. http://dx.doi.org/10.1080/10242690600722636

Malizard, J. 2015. "Does Military Expenditure Crowd Out Private Investment? A Disaggregated Perspective for the Case of France." Economic Modelling. Vol. 46, No. April, pp. 44-52.

http://dx.doi.org/10.1016/j.econmod.2014.10.049

Mankiw, N.G., D. Romer, and D.N. Weil. 1992. "A Contribution to the Empirics of Economic Growth." Quarterly Journal of Economics. Vol. 107, No. 2, pp.

The Economics of Peace and Security Journal — ISSN 1749-852X — http://www.epsjournal.org.uk 
$407-437$.

http://dx.doi.org/10.2307/2118477

Mylonidis, N. 2008. "Revisiting the Nexus between Military Spending and Growth in the European Union." Defence and Peace Economics. Vol. 19, No. 4, pp. 265-272. http://dx.doi.org/10.1080/10242690802164801

Pesaran, H.M., Y. Shin, and R.P. Smith. 1999. "Pooled Mean Group Estimation of Dynamic Heterogeneous Panels." Journal of the American Statistical Association. Vol. 94, pp. 621-634. http://dx.doi.org/10.1080/01621459.1999.10474156

Ramey, V.A. 2011. "Identifying Government Spending Shocks: It's All In The Timing." Quarterly Journal of Economics. Vol. 126, No. 1, pp. 1-50. http://dx.doi.org/10.1093/qje/qjq008

Reinhart, C. and K. Rogoff. 2010. "Growth in a Time of Debt." American Economic Review. Vol. 100, No. 2, pp. 573-578. http://dx.doi.org/10.1257/aer.100.2.573

Schmidt, O. 2013. "A Tragic Lack of Ambition: Why EU Security Policy is No Strategy." Contemporary Security Policy. Vol. 34, No. 2, pp. 413-416. http://dx.doi.org/10.1080/13523260.2013.808076

Sherpherd, A.J.K. 2015. "The European Security Continuum and the EU as an International Security Provider." Global Society. Vol. 29, No. 2, pp. 156-174. http://dx.doi.org/10.1080/13600826.2015.1018146

Smith, R.P. 2009. Military Economics: The Interaction of Power and Money. London: Palgrave MacMillian. http://dx.doi.org/10.1057/9780230244672

Temple, J. 2001. "Growth Effects of Education and Social Capital in the OECD Countries." OECD Economic Studies. Vol. 2001, No. 2, pp. 57-101.

Appendix: Unit root and cointegration tests For each variable and each period of analysis, Table A1 shows the results of the Im, Pesaran, and Shin unit root test (with intercept and lags determined by Akaike information criteria). The last line indicates the value of the Pedroni (rho) cointegration test (one intercept is included as an exogenous term).
Table A1: Unit root and cointegration tests

$\begin{array}{lcc} & 1960-2011 & 1988-2011 \\ \ln \left(y_{i, t}\right) & \begin{array}{c}\text { IPS stat }=-0.3758 \\ \text { Prob }=0.3535\end{array} & \begin{array}{c}\text { IPS stat }=2.5857 \\ \text { Prob }=0.9951\end{array} \\ \ln \left(s_{i, t}\right) & \text { IPS }=-1.2073 & \text { IPS stat }=-1.9149 \\ & \text { Prob }=0.1137 & \text { Prob }=0.1278 \\ \ln \left(h_{i, t}\right) & \text { IPS }=-1.8601 & \text { IPS }=-4.5631 \\ & \text { Prob }=0.0314 & \text { Prob }=0.0000 \\ \ln \left(m_{i, t}\right) & \text { IPS }=4.1981 & \text { IPS stat }=-0.6716 \\ & \text { Prob }=1 & \text { Prob }=0.2509 \\ \ln \left(\text { civil } l_{i, t}\right) & \text { IPS stat }=-1.0040 & \text { IPS stat }=-0.5566 \\ & \text { Prob }=0.1577 & \text { Prob }=0.2889 \\ \text { Pedroni test } & \text { Rho }=2.2039 & \text { Rho }=1.9485 \\ & \text { prob }=0.9580 & \text { Prob }=0.9743\end{array}$

